\title{
CASH ON DELIVERY PAYMENT SYSTEM IN ONLINE BUYING AND SELLING PERSPECTIVE OF SHARIA ECONOMIC LAW
}

\author{
Moh. Zarkasi \& Erie Hariyanto \\ 1, 2Postgraduate Students of Madura State Institute of Islamic Studies \\ J. Asemanis Dua, Larangan Tokol, Tlanakan, Kabupaten Pamekasan, Jawa Timur 69371 \\ Email: ${ }^{1}$ mohzarkasi4@gmail.com; ${ }^{2}$ erie@iainmadura.ac.id
}

\begin{abstract}
Observing the phenomenon of the rise of online buying and selling with cash on delivery (COD) payment systems that are not following consumer satisfaction, this research aims to discuss the view of Sharia economic law in the process of online buying and selling with the COD payment system. This type of research is literature research, using qualitative descriptive methods. Its approach is through normative and empirical legal approaches in the form of case studies. The results of this study concluded that based on the propositions of the Qur'an and hadith and the opinions of fiqh scholars, basically doing business is allowed as long as there is no element of gambling, fraud, riba, gharar, and dharar. In the case of online buying and selling with the COD payment system, if the goods sold are halal, it is clear that the quality and quantity of goods are between those offered by the seller and those received by the buyer; the payment is no element of fraud and addition, except for the postage agreed at the beginning, then according to Sharia economic law, the law can (mubah). However, conversely, if the practice of buying and selling online with COD payments, there are elements of gharar (unclear goods), riba (additional price without replacement), tadlis (fraud), and dharar (danger) that have an impact on harming sellers or buyers, then the law is haram.
\end{abstract}

Keywords: Cash on Delivery Payment; Syariah Economic Law

\begin{abstract}
Abstrak: Mencermati fenomena maraknya jual beli online dengan sistem pembayaran Cash on Delivery (COD) yang tidak sesuai dengan kepuasan konsumen, maka penelitian ini bertujuan membahas pandangan hukum ekonomi syariah dalam proses jual beli online dengan sistem pembayaran COD tersebut. Jenis penelitian ini adalah penelitian kepustakaan, menggunakan metode kualitatif yang bersifat deskriptif. Pendekatannya melalui pendekatan hukum normatif dan empiris dalam bentuk studi kasus. Hasil penelitian ini menyimpulkan bahwa berdasarkan dalil Alquran dan hadis serta pendapat para ulama fiqh, pada dasarnya berbisnis dibolehkan selama tidak ada unsur judi, penipuan, riba, gharar dan dharar. Dalam kasus jual beli online dengan sistem pembayaran COD, jika barang yang diperjual belikan barang yang halal, jelas kualitas dan kuantitas barangnya antara yang ditawarkan penjual dengan yang diterima pembeli, pembayarannya tidak ada unsur penipuan dan tambahan, kecuali untuk ongkos kirim yang disepakati di awal, maka menurut hukum ekonomi syariah, hukumnya boleh (mubah). Tapi sebaliknya, jika praktik jual beli online dengan pembayaran COD tersebut terdapat unsur gharar (ketidak jelasan barang), riba (tambahan harga tanpa pengganti), tadlis (penipuan), dan dharar (bahaya) yang berdampak merugikan penjual atau pembeli, maka hukumnya haram.
\end{abstract}

Kata kunci: Pembayaran Cash on Delivery; Hukum Ekonomi Syariah 


\section{Introduction}

Islamic economics is not much different from existing economics because it both studies people's behavior in economic activities in the form of production, distribution, and consumption and the selection of scarce resources, then allocates these resources to meet human needs. However, in Islam, all these activities are also based on faith in Allah because every economic activity is the worship and enslavement of man to its Creator. Islamic economics pays attention to the commercial aspects obtained by humans and the formation of systems in the behavior of economic life following the Islamic sharia order. $^{1}$

Economic activity in the framework of sharia is intended so that in carrying out economic activities, one must adjust to the rules of the Qur'an and hadith. It must be admitted that the Qur'an does not present detailed rules about norms in conducting economic and financial activities. However, it only mandates its values (principles). While the Hadith of the Prophet (peace be upon him) only describes some of the details of its operationalization, while economic interaction with all forms is constantly evolving with the times and the level of progress of human culture.

The more human culture develops, the more types of muamalah appear. However, it certainly does not mean that Islamic values or norms escape the economic problems that develop in the present and future. Therefore, there must be breakthroughs in economic problems that follow Islamic rules so that the economic law of Shari'ah arises. The emergence of Sharia economic law phenomenon is a

${ }^{1}$ Andiko, Toha, "Signifikansi Konsep Ekonomi Islam Dalam Transaksi Bisnis di Era Modern”, Jurnal Ilmiah Mizani, Vol. 4, No. 1 (2017), p. 11. result of the interaction of Islamic law and the National legal system, which was initially limited to family law or in the field of special civil law as understood so far. ${ }^{2}$

Sharia economy is teaching that prioritizes religious values and ethics in peace, which provides the value of profit relative to both parties concerned and shares existing losses so that it is not emphasized to one party only, so that sharia economy answers all the unrest of Muslims in carrying out economic activities without any worries and worries, because it is clear that in sharia economy it is forbidden to use improper means, far from being maysir (gambling), gharar (indiscrean), tadlis (fraud) and riba. Everyone who believes is commanded not to eat each other's wealth in a wrong way, as explained in the word of Allah surah Al-Nisa' verse 29. The explanation of the verse that obtaining graces, it should not be in a vanity way that is contrary to Islamic law because in buying and selling, it must be based on honesty and must not cheat that can harm others. Therefore, as a people of the Prophet, Muhammad should imitate the Prophet's nature of honesty and trust so that the graces obtained becomes a blessing in the world and the hereafter. ${ }^{3}$

The economic system of Shari'ah has a different system from others so that it has divine economic characteristics, attitudes, humanity, justice, and balance. ${ }^{4}$ Therefore, the economic activities of Shari'ah help regulate and achieve

${ }^{2}$ Neni Sri Imaniyati, "Asas dan Jenis Akad Dalam Hukum Ekonomi Syariah: Implementasinya Pada Usaha Bank Syariah", MIMBAR, Vol. XXV, No. 2 (Desember 2011).

${ }^{3}$ Runto Hediana \& Ahmad Dasuki Aly, "Transaksi Jual Beli Online Perspektif Ekonomi Islam”, Jurnal AlMustashfa, Vol. 3, No. 2 (2015), p. 42.

${ }^{4}$ Musyfikah Ilyas, “Tinjauan Hukum Islam Terhadap Musyawarah Dalam Penyelesaian Sengketa Ekonomi Syariah", Jurnal Al-Qadau, Vol. 5, No. 2 (Desember 2018), p. 113 
a decent degree of life for all individuals in a society that is following Islam. In addition, the Islamic economic system throughout the activities and habits of society is dynamic and fair in the division of income and wealth, by giving the right to each individual to earn a decent and noble livelihood both in the present world and in the hereafter. ${ }^{5}$

One of the muamalah in today's economic field is buying and selling transactions that use the Cash On Delivery payment system (from now on, abbreviated as COD). Cod buying and selling is a buying and selling between the seller and the buyer that begins with an agreement to meet somewhere. Then the seller hands over the goods, and the buyer checks the goods; if the buyer is satisfied, the money is handed over. However, the phenomenon that exists in most COD systems carried out at this time is not the same or much different from the COD system which buyers only see goods through online media without seeing the shape and quality of goods directly, and then the payment is made after an agreement between the seller and the buyer in the buying and selling media.

The existence of the COD system causes losses to one party because buyers sometimes do not receive appropriate orders on the agreement through the media. Consumers already use many online buying and selling applications, and many consumers are dissatisfied with the system. In this case, there is a case of COD fraud on social media that is widely discussed. For example, a person is surprised when a courier carries two packages with COD payments on his behalf and behalf of his grandmother. When he received the

\footnotetext{
${ }^{5}$ Kelik Pramudya, "Strategi Pengembangan Ekonomi Syariah Melalui Penguatan Fungsi Pengadilan Agama Dalam Penyelesaian Sengketa", RechtsVinding, Vol. 7, No. 1 (April 2018), p. 71.
}

package, he claimed that none of his family members were waiting for the package or buying goods online, saying he had a habit of paying early when buying online shop. Because it feels not ordering any goods, finally returned to the courier, while the nominal listed is quite expensive. He conveyed the losses suffered from the incident, namely his identity and home address spread by irresponsible individuals. Because the tweet became crowded, several other netizens also shared similar stories; some even suffered losses due to identity leaks and lost money. ${ }^{6}$

From the context of the problem, Islamic law is based on sharia economic rules of course there are specific discussions that can conclude the existence of legal patents or not buying and selling with the COD system. Several previous studies have also discussed the sale and purchase of online from various sides according to Islamic law, one of which is Runto \& Ahmad research, namely to find out in depth transactions in online buying and selling or e-commerce OLX.co.id (bagus. com store). Runto \& Ahmad elaborated in carrying out buying and selling transaction activities; a seller must explain how the condition of the goods and try to apply the principle of honesty in transacting, allowed to make buying and selling transactions over the phone, if the conditions described can be realized, for example by knowing the price and type of goods and the absence of goods. Using social media and other forms of media can be taken advantage of to facilitate and be able to survive things that can lead to harm. ${ }^{7}$

In line with queen Humaemah's research, he found that in terms of buying and selling,

\footnotetext{
${ }^{6}$ https://www.kompas.com accessed on 24 March 2021 at 09:23.

${ }^{7}$ Runto Hediana \& Ahmad Dasuki Aly, "Transaksi Jual Beli...”, p. 43.
} 
the honesty factor becomes very important, because as a trait that will help the human person himself provide clear information about the product, ranging from type, color, quality, to the time of delivery of goods. This is the most important thing so that no one feels cheated or aggrieved because every transaction that does not bring benefits then cancels the transaction, and if the transaction is beneficial, it is allowed. ${ }^{8}$ Therefore, the author needs to conduct an in-depth study devoted to the COD payment system in online buying and selling".

\section{Method}

This type of research is literature research using qualitative descriptive research methods in case studies. The approach used is a normative (Islamic sharia) and empirical legal approach with primary and secondary legal materials. A normative legal approach is the study of the legal norms from a data source relevant to the study. Primary legal material is derived from provisions in the Quran and hadith, while secondary legal materials are taken from various kinds of literature as a support for discussion. At the same time, the empirical approach as a field approach support the validity of existing data and facts, especially in the practice of cash on delivery payment systems in online buying and selling.

\section{Basic Concepts of Buying and Selling}

Buying and selling in fiqh terms is called al-bai' which means selling, replacing, and exchanging something for something else. Lafal al-bai' in Arabic is sometimes used to understand his opponent, namely the word

\footnotetext{
${ }^{8}$ Ratu Humaemah, "Analisa Hukum Islam Terhadap Masalah Perlindungan Konsumen Yang Terjadi Atas Jual Beli E-Commerce", Islamiconomic, Vol. 6, No. 1 (2015), p. 37.
}

al-syira (buy). ${ }^{9}$ While in terms of "exchanging property based on consensual". According to Ibn Qudamah, the notion of buying and selling is "exchanging property for mutual property". ${ }^{10}$ While according to Hasbi ashShiddieqy, buying and selling is an agreement to exchange property with other property to become a permanent property exchange. ${ }^{11}$ Buying and selling is a helpful activity between fellow human beings who have a solid foundation in Islam, both in the form of the Qur'an, Hadith, and Ijma'. According to the Civil Code and The Civil Procedure, also mentioned in the fifth Chapter on Buying and Selling article 1457: "Buying and selling is an agreement, with which one party binds itself to surrender a material, and the other party to pay the promised price." 12

He said that he was talking about buying and selling based on the propositions of The Word of Allah in surat al-Baqarah verse 275: "Those who eat riba cannot stand but as the establishment of those who enter satan out of the madness. That is because they say buying and selling is the same as riba. Allah has legalized the sale and prohibits usury. Those who have come to him are sent to him and continue to cease, and what he has gained belongs to him and his business to Allah. Whoever repeats, they are the inhabitants of hell; they remain in it. ${ }^{13}$ Moreover, there are many more hadith propositions explaining

\footnotetext{
${ }^{9}$ Wati Susiawati, "Jual Beli Dalam Konteks Kekinian", Jurnal Ekonomi Islam, Vol. 8, No. 2 (November 2017), p. 129.

${ }^{10}$ Siti Mujiatun, "Jual Beli Dalam Perspektif Islam: Salam dan Istisna”, Jurnal Riset Akutansi dan Bisnis, Vol. 13, No. 2 (September 2013), p. 117.

${ }^{11}$ Hasbi Ash-Shiddieqy, Pengantar Fiqih Muamalat, (Jakarta: Bulan Bintang, 1989), p, 97.

12 Kitab Undang-Undang Hukum Perdata (KUHPerdata) dan Kitab Undang-Undang Hukum Acara Perdata (KUHAPer), (Yogyakarta: Pustaka Yustisia, 2015), p. 199.

13 Siti Mujiatun, “Jual Beli...”, p. 118.
} 
buying and selling, but researchers only list some of them. In buying and selling, following Islamic sharia must meet several provisions to be said to be legitimate. Therefore, the pillars and conditions cannot be separated because the contract in buying and selling must meet the requirements and pillars. The majority of scholars set four pillars of buying and selling, namely: two people who are doing akad (buyer and seller), there is a pronunciation of ijab qabul, ma'qud 'alaih (goods sold), a legitimate medium of exchange (money). ${ }^{14}$ The terms that sellers and buyers must own include 1) The terms of people doing business include being intelligent, meaning crazy people or people who have not been mumayiz (puberty and intelligent) is not valid, and those who do the contract must be different people. 2) The conditions related to ijab and qabul, all scholars agree that the main element in buying and selling is the willingness of both parties.

The scholars' fiqh argues that the conditions in ijab qabul include: people who say have puberty and be intelligent, qabul that is carried out must be following ijab, then ijab and qabul must be carried out in one council. 3) The terms of the goods sold (ma'qud alaih), among others: goods exist or are not in place, but the seller declares his ability to hold the goods and can function or function. 4) Goods already have their owners, may be submitted at the time of the contract or the specified time when the transaction takes place. 5) The condition of the exchange rate (the price of goods), classified as a fundamental element in buying and selling, is the exchange rate, and most people use money. Related to exchange rates, the scholars of fiqh distinguish between al-tsaman and al-si'r. Tsaman is the market

14 Syaifullah, "Etika Jual Beli Dalam Islam", Jurnal Studia Islamika, Vol. 11, No. 2 (Desember 2014), p. 201. price that occurs during society, while al-sir is the capital of goods that all traders should receive before being sold to consumers. ${ }^{15}$ So if the conditions and pillars of buying and selling are fulfilled, it can be viewed as legitimate.

As for the kinds of buying and selling, Imam Taqiyuddin argued that based on the object, buying and selling could be classified into three groups, namely: first, buying and selling visible objects. In this buying and selling, the goods traded are in front of the eyes of sellers and buyers. Second, buying and selling objects that are only mentioned by its properties, this buying and selling occur when sellers and buyers transact, but the goods traded are not in sight, and only mentioned the properties by the seller, usually occurs in greeting agreements. So a buying and selling agreement like this is identical to buying and selling in the indent. Third, buy and sell things that do not exist. Buying and selling like this is a buying and selling that is prohibited in Islam, because the goods sold are unclear and still vague. ${ }^{16}$

\section{Cash on Delivery (CoD) Payment System}

Before explaining the understanding of COD, it would be better to know first and sell online or can be called e-commerce systems or service and information technology. This is done electronically, and business process applications connect with the company in commerce between consumers or communitas through buying and selling transactions. The

${ }^{15}$ Akhmad Farroh Hasan, Fiqih Muamalah dari Klasik Hingga Kontemporer, (Malang: UIN-Maliki Malang Press, 2018), p. 32-33.

16 Uyunul Husniyyah, “Tinjauan Fiqh Muamalah Terhadap Akad Jual Beli Online Pada Layanan Go-Mart di Aplikasi G0-Jek", Amwaluna: Jurnal Ekonomi dan Keuangan Syariah,Vol. 2, No. 2 (Desember 2020), p.121. 
notion of e-commerce quoted by Muhammad and Alimin is narrowly interpreted as buying and selling products, services, and information between business partners through computer networks, including the internet. ${ }^{17}$ So e-commerce can be interpreted as a liaison when buyers and sellers are met in cyberspace, as a way to shop or trade online by utilizing the internet as a medium, ranging from ordering transaction payment goods to the delivery of goods communicated over the internet. Furthermore, the meaning of COD stands for Cash on Delivery which means Cash in Indonesian is cash, and delivery, which means delivery. These two words, in a narrow sense, can be interpreted to pay on the spot or meet directly between sellers and buyers face-toface. Buying and selling cod is buying and selling when the seller and the buyer start with an agreement to meet somewhere, then the seller hands the goods, and the buyer checks the goods; if the buyer is satisfied, then the money is handed over. Such a system adheres to the principle of the existence of goods; of course, there must be money. ${ }^{18}$ Using the COD method is one of the payment methods where the buyer and the seller agree to pay when the purchased goods reach the delivery address. This akad can be said to be a greeting agreement that is an order buying and selling agreement (muslam fiih) with the delivery of goods later by the seller (muslam illaihi), and the buyer makes the repayment at the time the agreement is agreed following certain conditions. ${ }^{19}$

17 Muhammad \& Alimin, Etika \& Perlindungan Konsumen dalam Ekonomi Islam, (Yogyakarta : BPFE, 2014), p, 288.

${ }^{18}$ J. Setyaji dan Agus W, Jualan Laris dan Beli Aman Buat Angan-Angan di Forum Jual Beli Kaskus, (Jakarta Selatan: PT Trans Media, 2011), p, 41.

19 Mahkamah Agung, Kompilasi Hukum Ekonomi Syariah (Edisi Revisi), (Jakarta: Mahkamah Agung, 2011), p. 14.
In the view of Islamic fiqh, the buying and selling order according to the language of the Hijaz population is called al-salam, and according to the language of the Iraqi population is called al-salaf, but these two words have the same meaning. The words al-salam and al-salaf were once used by the Prophet Muhammad ( peace be upon him). The Prophet narrated that when talking about bai'al-salam, he used the words al-salaf and al-salam, so that the two words have similar meanings between one word and another even though the word is different. ${ }^{20}$ Thus, bai' alsalam has particular criteria compared to other buying and selling because the payment is made in front (kontan in the place of the contract), so that this sale is called al-salaf. The characteristics of the goods ordered must follow the shape and color agreed between the two. If things happen that do not match the ordered goods delivered, such as wrong or defective, then the seller must be responsible for replacing them. The legal basis for buying and selling greetings:

"The Prophet said: three things in which there are blessings: buying and selling that gives tempo, borrowing, and a mixture of wheat with barley (grain) to be used as the food of the people of their own homes, not for sale." (HR. Ibn Majah of Shuhaib). ${ }^{21}$

The permissibility of transactions or buying and selling with al-salam aims to obtain convenience in running a business because the goods can be sent later. If there is fraud or goods not following the order, then the customer or entrepreneur has the right to cancel it or continue it with compensation such as reducing the price. Using bai' al-salam transactions, there are pillars and conditions,

\footnotetext{
${ }^{20}$ Munir Salim, "Jual Beli Secara Online Menurut Pandangan Hukum Islam”, Al-Daulah, Vol. 6, No. 2 (Desember 2017), p. 124.

${ }^{21}$ Siti Mujiatun, Jual Beli Dalam...”, p. 118
} 
the pillars of buying and selling greetings are: first, the existence of al-Muslim (buyer) transactions and muslam ilaihi (sellers); second, modal (ra'su mal al-salam); Third, there is shighah (ijab qabul) both written and spoken. $^{22}$

The conditions include payment made at the time of the contract (transaction). As understood from its name, al-salam (surrender) and al-salaf (precedence). The goods must mention the criteria, the number and size of goods when the transaction takes place in the greeting sale and purchase agreement, between the seller and the buyer, must agree on the criteria of the goods that have been ordered, such as the type and type, color, size, number of goods, and the properties of the goods desired and affect the price of the goods. In order to avoid conflict between sellers and buyers, you should explain in advance the nature of the goods so as not to cause doubts that can harm others. Likewise, it must also be mentioned, for example buying goods that are quickly damaged or rotten must be listed where to receive it, whether the place is worthy or not to receive the item. ${ }^{23}$ Differences of opinion regarding the permissibility of goods sold by greeting are given directly or suspended, this opinion according to imam Shafi'i, Hanafi, and Maliki. While it is not permissible to hand over goods directly, and of course, there must be a suspension, although a few days, this is in the opinion of imam Hambali.

Result and Discussion on the Review of Economic Sharia Law on Cash on Delivery Payment System in Online Buying and Selling

All transactions and deeds in the field of muamalah are allowed as long as no proposition

\footnotetext{
${ }^{22}$ Siti Mujiatun, Jual Beli Dalam...”, p. 119.

${ }^{23}$ Munir Salim, “Jual Beli Secara...", p. 125.
}

of the Qur'an and hadith mentions its prohibition. Of course, many new problems arise, so there still needs to be a study that discusses the new problem. There are many trade transactions through cyberspace (online or via the internet) in today's digital age, so between sellers and buyers is not limited by space and time.

Using online media transactions in the application provided to put goods by the seller on a website is information so that it can be read and seen by internet users, and this can be said to be ijab. While buyers interested in the item can complete the data and send applications that the buyer has filled, this is called qabul. ${ }^{24}$ The item can only be seen in images or photos without knowing the shape directly and explained the specifications thoroughly in giving a description that affects the item's price. After an agreement between the seller and the buyer (sighat), the buyer transfers money to the seller's account. After the money is received, the seller will send his goods through courier or freight forwarding services.

According to maxmanroe.com, in this online buying and selling, there are 3 types of buying and selling transactions commonly carried out in Indonesia, namely: first, interbank transactions are the most common and popular types of transactions used by online sellers. In addition to being relatively simple, this type of transaction also facilitates the confirmation process because funds can be quickly checked by the recipient/seller. The following payment system is slightly different from via bank transfer because this system uses a third party trusted to receive money. This payment system is called a joint account (escrow). Moreover, third, there is also Cash

${ }^{24}$ Munir Salim, “Jual Beli Secara...”, p. 126. 
On Delivery. The COD system actually still adheres to the old way of meeting between sellers and buyers. Usually, this transaction system is done in buying and selling between people to people, and in general, COD is used for second goods because buyers must check the condition of the goods. ${ }^{25}$

However, because of the development of electronic systems, especially in buying and selling that was initially a COD system, usually begins with an agreement between the seller and the buyer when there is an agreement, then the money is handed over. Currently, the meaning of COD shifts no longer just in the form of a direct meeting between sellers and buyers. Several marketplaces provide COD services with payment methods done directly on the spot with orders from couriers, then received by buyers without face-to-face with the seller. A service system like this is intended to facilitate online buying and selling transactions, especially for reluctant buyers or those who are still not familiar with online payments, such as bank transfers or the use of money or digital wallets. ${ }^{26}$

What needs to be understood, each marketplace itself has different rules in the use of COD payments. Such as the minimum terms of spending until the obligation adds to the cost of shipping insurance. However, to be sure, buyers are not allowed to unpack the packaging before paying with cash according to the purchase price and shipping costs to the courier. Meanwhile, if it is known that the goods ordered through COD are not appropriate or defective/damaged, the marketplace has provided a complaint feature

${ }^{25}$ Desy Safira \& Alif Ilham Akbar Fatriansyah, "Bisnis Jual Beli Online Dalam Perspektif Islam”, Al-Yasini Vol. 5, No. 1 (Mei 2020), p.83

${ }^{26} \mathrm{https} / / /$ money.kompas.com accessed on 30 March 2021 at $22: 21$. that connects sellers and buyers. If a complaint is received, the buyer will get a replacement item or other replacement in the form of a refund. If the buyer feels he has never ordered, the buyer can also refuse the goods delivered by the courier and do not have to pay for them. The goods will be received by the courier back, then sent back to the seller's address.

The use of COD also usually results from more expensive shipping costs due to limited selection options. If the buyer chooses to use the COD payment method but refuses when the courier delivers the goods, then the marketplace usually has a data collection system. Buyers who have rejected goods delivered via COD will usually be blocklisted and can no longer use the service. ${ }^{27}$

For buyers of COD payment methods by paying on the spot when goods come, of course, there are maslahah and mafsadah where the author interviews residents in Kangenan village, the maslahah is happy with the existence of this COD system. The shopping process is easy, order the goods, and payment can be made on the spot. Systems like this also save time and effort; there is no need to go around the mall or store because it is enough to spend a while by opening the internet. COD payments like this minimize lies because there is often fraud by not sending goods after the payment is made. The disadvantages of the COD system have risks such as goods received are not in accordance with online buying and selling transactions in general and goods that do not match what is ordered both from the size, shape, and color, and damaged package. Although some marketplaces implement policies when

${ }^{27}$ Desy Safira \& Alif Ilham Akbar Fatriansyah, "Bisnis Jual Beli...”, p. 84 . 
goods do not match, orders can be returned. However, things like this certainly still harm consumers as buyers of returned goods because they still bear the cost. Therefore, the majority of consumers do not reverse the goods because they still incur additional costs.

Islamic views in doing business online are allowed as long as there are no elements of usury, tyranny, politics, and fraud. The danger of riba is several statements in the Qur'an, including surah Al-Baqarah verses 275, 279, and 278; Surah Al-Rum Verse 39; and surah Al-Nisa verse $131 .^{28}$ Thus, the COD system with pay on the spot in terms of buying and selling is legitimate because this COD system still exists ijab and qabul. So as long as the ijab and qabul are no different, for example, different goods and prices and payment times, or not opposite either in matters of goods, prices or even in cash matters, then the sale is considered legitimate.

In the madzhab Al-Shafi'i, buying and selling can be represented to others to sell or buy an item. Everything can be done alone. One can represent oneself to others and may receive representation from people. Therefore, transactions through couriers or delivery services can legally be done. However, note that the courier or delivery service has a letter of duty or power of attorney in making the sale. Because of the sale and purchase of fudhuli (selling the property of others without the power of attorney or representation), the law is void. A representative may not make a buying and selling transaction except on three conditions: first, let him sell the mandated goods at the prevailing price based on the calculation of money circulating in his area;

${ }^{28}$ Tira Nur Fitria, "Bisnis Jual Beli Online (Online Shop) Dalam Hukum Islam dan Hukum Negara”, Jurnal Ilmiah Ekonomi Islam, Vol. 03, No. 01 (Maret 2017), p. 27.
Second, it does not sell to itself; Third, it shall not name the person representing except with permission. ${ }^{29}$

Transactions through this courier in Fiqh Madzhab Al-Shafi'i are called buying and selling with wakalah (representative). Wakalah or wikalah isim mashdar, which etymologically means taukil i.e., handing over or representing and maintaining. Wakalah is allowed by sharia based on hadith: "From Urwah the Prophet (peace be upon him) gave him one dinar, in order to buy him a goat. So Urwah bought two goats for him, and 'Urwah sold one of his goats for one dinar. Urwah gave one dinar and a goat to the Prophet. So he prayed for Urwah with blessings in his buying and selling. If Urwah buys land, he will be very profitable." (HR. Bukhari).

Things that are not allowed in Islam when doing business online are fraud and fraud. However, consumers feel disappointed with this system, back to the seller himself, who must have the honest nature as the principal capital. So there is nothing wrong with the online buying and selling system with the $\mathrm{CoD}$ payment system because paying on the spot does not violate Islamic sharia. Other parties want to take advantage of a system like this by doing wrong to consumers so that consumers feel financially harmed.

Meanwhile, according to MUI, purchase transactions made by consumers through the ordering application include bai' maushufun $\mathrm{fi}$ al-dzimmah, which is the sale and purchase of goods independents and legally.' This transaction in the context of figh muamalah is also known as a greeting transaction (order). ${ }^{30}$ Buying and

${ }^{29}$ Retno Dyah Pekerti \& Eliada Herwiyanti, “Transaksi Jual Beli Online Dalam Perspektif Syariah Madzhab AsySyafi'i”, JEBA Vol. 20, No. 02 (2018), p. 112.

${ }^{30}$ Sumber: https://islam.nu.or.id accessed on 5 April 2021, at $09: 35$. 
selling agreements, either conventionally or online, are protected in Law No.8 of 1999 on consumer protection. The Act regulates the rights and obligations of consumers and business actors. The rights and obligations of consumers and violations in cyberspace are regulated in article 9 of Law No. 11 of 2008 concerning Information and Electrical Transactions. In addition, it prohibits the spread of false and misleading news that results in consumer losses in electronic transactions, as stated in Article 28 paragraph (1). ${ }^{31}$

The author gives opinions and steps that can be taken to allow online buying and selling, halal, and legal according to Islamic sharia, including the product must be halal. This is important because in Islamic sharia, what takes precedence is about its halalharam, both business buying and selling as usual and online. Because in buying and selling, when in it mixed with illegal or unclean things and the like, it should not be traded. In addition to violating the Shari'ah against what is forbidden by Allah and his Prophet, it can also be harmful to humankind. Among the forbidden such as khamar, carcasses, pigs, and statues. Next, there is clarity of status.

Given that in conducting a buying and selling transaction, what needs to be seen is clarity of status because something is speculation or vague, it is illegal to trade because it can harm one party, the seller, and the buyer. Next is the suitability of the price with the superiority of the goods. Many found, consumers feel aggrieved after knowing and receiving the goods, such as pants purchased online are not appropriate when accepted or uncomfortable to wear

31 Diah Syifaul A'yuni, "Konsep Jual Beli Online Menurut Perspektif Hukum Islam”, $A L-A D A L A H$, Vol. 3, No. 1 (Maret 2018), p. 61. because of the quality of the fabric itself and the size that does not fit the body. Therefore, before or after this happens, it should be appropriately considered whether the price offered is under the quality of the goods to be purchased. The last one is honesty. Although buying and selling online has many advantages and conveniences, it does not mean there are no problems. Of course, problems can occur in buying and selling online if there are terrible intentions from producers/sellers and consumers.

So most importantly, both parties must have a sense of trust, both the seller and the buyer. The saying goes that being honest is a tip to congratulations. Therefore, honesty is the essential thing that must take precedence.

\section{Conclusion}

In the framework of Sharia economic law, the system of cod distribution on online buying and selling is allowed because it does not conflict with the provisions of the Qur'an and hadith. It contains many facilities and advantages and in the study of fiqh including the account bai' maushufun $f_{i}$ al-dzimmah, namely the sale and purchase of goods independents. This transaction in the context of figh muamalah is also known as a greeting transaction (order). Such accounts and payment systems are allowed with a commitment to honesty between the seller and the buyer. In addition, this COD system still exists ijab and qabul, so while in ijab and qabul, there is no opposite, either in matters of goods, prices, or price and payment. Transactions through this courier in Fiqh Madzhab Asy-Shafi'i are called buying and selling with wakalah (representative). A representative should not make a buying and selling transaction except on three conditions. First, should sell goods mandated at the 
prevailing price based on the calculation of money circulating in his area; Second, not sell to himself; Third, it is not permissible to name the person representing except with permission. Thus, the payment system with the COD system in online buying and selling is a disaster. The law can turn illegal if there is an element that harms or harms one of the parties, both sellers and buyers.

\section{References}

Afrida, Yenti, "Analisis Pembiayaan Murabahah di Perbankan Syariah", JEBI, Vol. 1, No. 2 (Juli-Desember 2016).

Andiko, Toha. "Signifikansi Konsep Ekonomi Islam Dalam Transaksi Bisnis di Era Modern”, Jurnal ilmiah Mizani, Vol. 4, No. 1 (2017).

Beli Kaskus, Jakarta Selatan: PT Trans Media, 2011.

A'yuni, Diah Syifaul. "Konsep Jual Beli Online Menurut Perspektif Hukum Islam", $A L$ ADALAH, Vol. 3, No. 1 (Maret 2018).

Fitria, Tira Nur. "Bisnis Jual Beli Online (Online Shop) Dalam Hukum Islam dan Hukum Negara", Jurnal Ilmiah Ekonomi Islam, Vol. 03, No. 01 (Maret 2017).

Hasan, Akhmad Farroh. Fiqih Muamalah dari Klasik Hingga Kontemporer, Malang: UINMaliki Malang Press, 2018.

Humaemah, Ratu. "Analisa Hukum Islam Terhadap Masalah Perlindungan Konsumen Yang Terjadi Atas Jual Beli E-Commerce", Islamiconomic, Vol. 6, No. 1 (2015)

Husniyyah, Uyunul. “Tinjauan Fiqh Muamalah Terhadap Akad Jual Beli Online Pada Layanan Go-Mart di Aplikasi G0-Jek", Amwaluna: Jurnal Ekonomi dan Keuangan Syariah, Vol. 2, No. 2 (Desember 2020).

Ilyas, Musyfikah. "Tinjauan Hukum Islam Terhadap Musyawarah Dalam Penyelesaian Sengketa Ekonomi Syariah", Jurnal AlQadau, Vol. 5, No. 2 (Desember 2018).
Imaniyati, Neni Sri. "Asas dan Jenis Akad Dalam Hukum Ekonomi Syariah: Implementasinya Pada Usaha Bank Syariah", MIMBAR, Vol. XXV, No. 2 (Desember 2011).

Kitab Undang-Undang Hukum Perdata (KUHPerdata) dan Kitab Undang-Undang Hukum Acara Perdata (KUHAPer), Yogyakarta: Pustaka Yustisia, 2015.

Mahkamah Agung RI, Kompilasi Hukum Ekonomi Syariah, Edisi Revisi, Jakarta: Mahkamah Agung RI, 2011.

Muhammad \& Alimin, Etika \& Perlindungan Konsumen dalam Ekonomi Islam, Yogyakarta: BPFE, 2004.

Mujiatun, Siti. "Jual Beli Dalam Perspektif Islam: Salam dan Istisna', Jurnal Riset Akutansi dan Bisnis, Vol. 13, No. 2 (September 2013).

Pekerti, Retno Dyah \& Eliada Herwiyanti. "Transaksi Jual Beli Online Dalam Perspektif Syariah Madzhab Asy-Syafi'i”, JEBA, Vol. 20, No. 02 (2018).

Pengadilan Agama Dalam Penyelesaian Sengketa", Rechts Vinding, Vol. 7, No. 1 (April 2018).

Pramudya, Kelik. "Strategi Pengembangan Ekonomi Syariah Melalui Penguatan Fungsi

Runto Hediana \& Ahmad Dasuki Aly. "Transaksi Jual Beli Online Perspektif Ekonomi Islam”, Jurnal Al-Mustashfa, Vol. 3, No. 2 (2015).

Safira, Desy \& Alif Ilham Akbar Fatriansyah. "Bisnis Jual Beli Online Dalam Perspektif Islam”, Al Yasini, Vol. 5, No. 1 (Mei 2020).

Sengketa Ekonomi Syariah", Al-Qadau, Vol. 5, No. 2 (Desember 2018).

Salim, Munir. "Jual Beli Secara Online Menurut Pandangan Hukum Islam", Al-Daulah, Vol. 6, No. 2 (Desember 2017).

Setyaji, J. dan Agus W. Jualan Laris dan Beli Aman Buat Angan-Angan di Forum Jual Beli Kaskus, Jakarta Selatan: PT Trans Media, 2011. 
Susiawati, Wati. "Jual Beli Dalam Konteks Kekinian”, Jurnal Ekonomi Islam, Vol. 8, No. 2 (November 2017).
Syaifullah. "Etika Jual Beli Dalam Islam”, Jurnal Studia Islamika, Vol. 11, No. 2 (Desember 2014). 